\title{
Urgensi Penguatan Payung Hukum dalam Pengembangan Objek Wisata di Kabupaten Jepara
}

\author{
Restu Andi Zulianto ${ }^{1}$, Nanik Prasetyoningsih ${ }^{2}$ \\ ${ }^{1,2}$ Program Studi Hukum, Fakultas Hukum, Universitas Muhammadiyah Yogyakarta, Indonesia \\ Jl. Brawijaya, Tamantiro, Kasihan, Bantul, Yogyakarta \\ E-mail: ${ }^{1}$ restu.andi.2013@law.umy.ac.id; ${ }^{2}$ nanikprasetyoningsih@umy.ac.id
}

\section{Info Artikel}

Diajukan: 22-02-2020

Direview: 26-03-2020

Direvisi: $30-03-2020$

DOI: $10.18196 / \mathrm{mls} . v 1 i 2.8347$
Diterima: 01-04-2020

\section{Abstrak}

Kabupaten Kabupaten Jepara merupakan daerah otonom yang berada di Provinsi Jawa Tengah. Potensi pengembagan objek pariwisata di Kabupaten Jepara sangat sangat prospektif, mengingat Kabupaten ini terletak di antara tepi Pantai dan bukit-bukit kecil yang menyajikan panorama indah dan eksotik. Diperlukan payung hukum yang kuat agar legitimasi pengeolaan objek pariwisata menjadi berkemanfaatan dan berkapastian hukum. Masih banyak yang perlu dibenahi terkait pengelolaan dan pemanfaatn objek wisata yang ada di Kabupaten Jepara seperti infrastruktur jalan, penginapan, dan desain fasilitas kebersihan termasuk ketersediaan toilet umum yang hieginis. Penelitian ini merupakan normatif-empiris yakni dengan kajian pustaka disertai data primer berupa wawancara, pengamatan, dan observasi. Hasil penelitian menimpulkan bwelum optimalnya dukungan kebijakan hukum di bidang pariwisata Jepara. Riset ini merekomendasikan pentingnya pembuatan payung hukum dan penegakan hukum dalam rangka mendukung pengembangan objek-objek wisata yang terdapat di Kabupaten Jepara. but tidak merata sehingga bisa dikatakan kebijakan itu belum optimal.

Kata kunci: kebijakan, pariwisata jepara, pemerintah daerah.

\section{Pendahuluan}

Pariwisata memiliki peran yang besar dalam pembangunan nasional. Karena selain menghasilkan pendapatan dan sekaligus sebagai penghasil devisa, Usaha Pariwisata adalah kegiatan yang bertujuan menyelenggarakan jasa pariwisata atau menyediakan atau mengusahakan objek dan daya tarik wisata ${ }^{1}$, Untuk meningkatkan kemajuan di daerah Kota Jepara. Berbagai upaya harus dilakukan oleh pemerintah daerah secara langsung terutama dibidang regulasi daerah. Upaya yang dilakukan Pemerintah daerah Kota Jepara melalui Dinas Pariwisata tidak terlepas dari hambatan maupun kendala tetapi seoptimal mungkin kendala itu harus dapat di atasi, mengingat ada banyaknya objek wisata di Kabupaten Jepara yang perlu di tingkatkan pengembangannya.

Jepara menawarkan berbagai macam objek wisata yang mempunyai ciri khas unik seperti berenang dengan ikan hiu di Karimun Jawa, keindahan alam yang luar biasa serta wisata budayanya (Museum Kartini, tradisi lainnya) yang patut dilestarikan kepada

${ }^{1}$ Deddy Prasetya Maha Rani, Pengembangan Potensi Pariwisata Kabupaten Sumenep, Madura, Jawa Timur, Jurnal Politik Muda, Vol. III No.3, Agustus-Desember 2014, hlm. 143. 
generasi penerus. Pada sektor pariwisata mempunyai kedudukan yang cukup strategis dalam pembangunan di kabupaten Jepara setelah sektor pertanian dan industri furniture. Pengembangan pada sektor pariwisata menjadi tekat pemerintah kabupaten Jepara karena pergerakan wisatawan di daerah ini mampu menggerakkan roda perekonomian masyarakat sekitar khususnya usaha kecil ataupun menengah di Kabupaten Jepara ${ }^{2}$

Dinas Pariwisata dan kebudayaan Kabupaten Jepara adalah instansi yang bertanggung jawab mengembangkan potensi-potensi dalam bidang kepariwisataan di Kabupaten Jepara. Terlebih Potensi-potensi yang berada di wilayah Kabupaten Jepara yang belum dikenal oleh publik. Potensi wisata alamnya, wisata religinya dan kebudayaannya yang perlu di kembangkan lagi oleh Pemerintah Daerah Kabupaten Jepara agar lebih tertata dengan baik guna menambah daya tarik wisata di Kabupaten Jepara. Wisata alamnya seperti pantai-pantai yang berada di sebagian wilayah Kabupaten Jepara yang sudah didirikan sarana prasarana wahana permainan maupun penginapan-penginapan yang menarik perhatian masyarakat luas. Wisata budayanya yang diselenggarakan secara rutin misalkan hari jadi Kota Jepara, karnaval serta peninggalan-peninggalan bersejarah seperti musium kartini dan benteng portugis yang di kelola dengan baik agar bisa menjadi media media pendidikan bagi generasi penerus.

Kurang meratanya pengembangan objek wisata yang ada di Kabupaten Jepara banyak wisatawan lokal luar kota atau wisatawan asing yang tidak mengetahui bahwa objek wisata di Kabupaten Jepara iu tidak cuma pantai saja tetapi masih banyak objek wisata lain misalnya air terjun atau pun hutan pinus yang baru-baru ini menjadi objek wisata Kabupaten Jepara yang baru. Untuk itulah dibutuhkan Kebijakan-kebiajakan Pemerintah daerah Kabupaten Jepara untuk meningkatkan dan mengembangkan objek wisata yang ada di Kabupaten Jepara. Rencana-rencana kebijakan Pemerintah daerah haruslah tepat sasaran dalam penerapannya agar tujuan-tujuan yang di inginkan dapat tercapai. Berdasarkan hal-hal tersebut jelaslah bahwa prospek pebngembangan objek pariwisata di Jepara mempunyai peluang yang besar jika dikelola dengan baik salah satunya adalah bagaiaman melakukan penguatan dibidang regulasi pariwisat sehingga pengembangan sektor pariwisata mempunyai payung hukum yang kuat.

\section{Metode Penelitian}

\subsection{Jenis Penelitian}

Jenis penelitian yang digunakan bersifat normatif emperik dengan bersumber pada data primer dan sekunder dimanan, data primer diperoleh langsung dari sumber di lapangan melalui sejumlah intrumen yang digunakan. Data Sekunder merupakan data yang tidak diperoleh secara langsung dari lapangan, melainkan diperoleh dari studi kepustakaan. Adapun data sekunder mencakup :

1. Bahan hukum primer terdiri dari:

\section{${ }^{2}$ Ibid.}


a. Undang-Undang Dasar Republik Indonesia Tahun 1945

b. Undang-Undang Republik Indonesia Nomor 23 Tahun 2014 Tentang Pemerintah Daerah.

c. Undang-Undang Republik Indonesia Nomor 10 Tahun 2009 Tentang Kepariwisataan.

d. Undang-Undang Republik Indonesia Nomor 28 Tahun 2009 Tentang Pajak Daerah dan Retribusi daerah.

e. Undang-Undang Republik Indonesia Nomor 9 Tahun 2015 Tentang Pemerintah Daerah.

f. Peraturan Daerah Kabupaten Jepara Nomor 9 Tahun 2016 Tentang Penyelenggaraan Usaha Pariwisata.

g. Peraturan Daerah Kabupaten Jepara Nomor 6 Tahun 2016 Tentang Perubahan Atas Peraturan Daerah Kabupaten Jepara Nomor 26 Tahun 2010 Tentang Retribusi Tempat Rekreasi.

2. Bahan hukum sekunder terdiri dari:
a. Buku-buku
b. Jurnal
c. Artikel
d. Internet
e. Hasil wawancara dengan responden

\subsection{Teknik Pengumpulan Data}

1. Wawancara dengan memberikan petanyaan kepada responden untuk mendapatkan informasi, keterangan, pandangannya atau pendapatnya mengenai kebijakan Pemerintah daerah dalam pengembangan objek wisata yang ada di Kabupaten Jepara.

2. Studi kepustakaan dari berbagai buku, surat kabar, jurnal, catatan, peraturan perundang-undangan, internet dan hasil wawancara dengan Responden. Studi kepustakaan bermanfaat untuk menyusun landasan teori yang akan menjadi tolak ukur untuk menganalisa hasil interprestasi data penelitian lapangan guna manjawab persoalan pada rumusan masalah.

\subsection{Responden}

Responden yaitu: Pihak-pihak yang dijadikan sebagai sampel dalam sebuah penelitian. Lebih tepatnya pihak yang terjun langsung atau ikut berkontribusi di lokasi penelitian. Yang menjadi Responden: 
1. Bapak Nad Jamrudin Eka menjabat sebagai Tata kelola destinasi Pariwisata di Dinas Pariwisata dan Kebudayaan Kabupaten Jepara.

2. Bapak Mad Khairun selaku ketua pengurus pantai Bandengan.

3. Bapak Eko selaku pengurus Desa Wisata Troso.

\subsection{Analisis Data}

Penelitian ini menggunakan metode diskriptif kualitatif yaitu menganalisa hasil penelitian lapangan dan penelitian kepustakaan, dengan tujuan memperoleh gambaran tentang kebijakan pemerintah daerah dalam pengembangan objek wisata yang ada di Kabupaten Jepara.

\section{Hasil dan Pembahasan.}

Kebijakan di bidang hukum pariwisata Kabupaten Jepara dalam pengembangan objek wisata sangat di butuhkan guna menarik wisatawan agar berkunjung ke Kabupaten Jepara. Hal ini sesuai dengan semangat yang terkandung dalam UndangUndang No. 10 Tahun 2009 Tentang Kepariwisataan. Oleh karena itu produk regualsi Peraturan Daerah dbidang pariwisati harus menjadi skala prioritas politik legislasi DPRD Kabupaten Jepara. Selain itu, harus ada kajian hukum secara komprehensi mengenai pentingnya produk regulasi pelaksana Perda Pariwisata sehingga tidak terjadi tumpang tindih regulasi yang terkait.

Pemerintah Jepara harus menyadari bahwa, pembangunan kepariwisataan dilakukan berdasarkan rencana induk pembangunan kepariwisataan yang terdiri atas rencana induk pembangunan kepariwisataan yang terdiri atas rencana induk pembangunan kepariwisataan nasional, rencana induk provinsi, dan rencana induk pembangunan kepariwisataan kabupaten/kota"3. Rencana induk pembangunan kepariwisataan kabupaten Jepara diatur lebih lanjut dalam Peraturan Daerah Kabupaten Jepara", Kendati kini telah ada Peraturan Daerah No. 9 Tahun 2016 Tentang Penyelenggaraan Usaha Pariwisata di Kabupaten Jepara, Perda ini perlu dievaluasi kembali seiring dengan kompleks permasalahan di bidang pariwisata terutam sektor Retribusi dan Perizinan. Sebelum ada payung hukum Peraturan Daerah ini, kebanyakan objek wisata di Kabupaten Jepara di kelola oleh masyarakat sekitar secara swadaya dan tidak tertata secara sistemik. Praktek pungutan liar masih sering terjadi dengan penenetuan tarif pungutan sepihak yang beragam tergantung objek wisata. Hal ini tentu berdampak pada minimnya pendapatan daerah (PAD) dan persepsi yang kurang baik bagi para pengunjung yang datang. Padahal, berdasarkan data satistik, terdapat tiga puluh lima objek wisata yang terbagi diseluruh wilayah Kabupaten Jepara. Objek wisata yang dimaksud mencakup wisata pulau, wisata sejarah, wisata pantai, wisata alam dan wisata buatan.

\footnotetext{
${ }^{3}$ Ketentuan Pasal 8 ayat (1) Undang-Undang No. 10 Tahun 2009 Tentang kepariwisataan.

${ }^{4}$ Ketentuan Pasal 9 ayat (3) Undang-Undang No. 10 Tahun 2009 Tentang kepariwisataan.
} 


\section{Tabel 1}

Daftar Objek Wisata Pulau dan Sejarah yang ada di Kabupaten Jepara

\begin{tabular}{|c|c|c|}
\hline Kategori & Nama Objek Wisata & Lokasi \\
\hline \multirow[t]{3}{*}{ Wisata Pulau } & Pulau Karimunjawa & $\begin{array}{l}\text { Karimunjawa satu satunya pulau kecil yang berpenghun } \\
\text { di kabupaten Jepara. untuk menyebrang ke karimunjawa } \\
\text { hanya bisa dilakukan di dermaga pantai kartini dan } \\
\text { waktu yang dibutuhkan dari dermaga sampai ke } \\
\text { karimunjawa membutuhkan waktu } 5 \text { jam menggunakan } \\
\text { kapal lambat sedangkan } 2 \text { jam untuk kapal cepatnya. }\end{array}$ \\
\hline & Pulau Mandalika & $\begin{array}{l}\text { Pulau mandalika pulau yang kecil dan tidak perpenghuni, } \\
\text { untuk menuju ke pulau mandalika bisa menggunakan } \\
\text { kapal kecil dan penyebrangannya dari pantai bandengan } \\
\text { Waktu yang dibutuhkan untuk sampai kesana hanya } 30 \\
\text { menit saja. }\end{array}$ \\
\hline & Pulau Panjang & $\begin{array}{l}\text { Pulau panjang ini terletak berdekatan dengan pulau } \\
\text { mandalika dan juga tidak berpenghuni. Penyebrangan di } \\
\text { lakukan di pantai bandengan dengan jarak tempuh } 30 \\
\text { menit dengan menggunakan kapal yang sudah disediakan } \\
\text { oleh pihak pengelolanya. }\end{array}$ \\
\hline \multirow[t]{5}{*}{ Wisata Sejarah } & Benteng Portugis & $\begin{array}{l}\text { Terletak didesa Banyumanis Kecamatan Donorojo } \\
\text { Kabupaten Jepara. }\end{array}$ \\
\hline & Ari-Ari Kartini & $\begin{array}{l}\text { Di desa Pelengkerep kecamatan Mayong Kabupaten } \\
\text { Jepara. }\end{array}$ \\
\hline & Makam Mantingan & $\begin{array}{l}\text { Di desa Mantingan Kecamatan Tahunan Kabupaten } \\
\text { Jepara. }\end{array}$ \\
\hline & Museum Kartini & $\begin{array}{l}\text { Tepatnya di Jl. Alun-alun No.1 Panggang Kecamatan } \\
\text { Jepara Kabupaten Jepara. }\end{array}$ \\
\hline & $\begin{array}{l}\text { Klenteng Hian Khian } \\
\text { ST }\end{array}$ & $\begin{array}{l}\text { Di Jl. Gg. Pinggir No. } 4 \text { Gedanganbrang, Kecamatan } \\
\text { Welahan Kabupaten Jepara. }\end{array}$ \\
\hline
\end{tabular}

Sumber: Dinas Pariwisata dan Kebudayaan Kabupaten Jepara, (2018)

Tabel 2

Daftar Objek Wisata Pantai dan Wisata alam di Kabupaten Jepara

\begin{tabular}{cll}
\hline Kategori & Nama Objek Wisata & Lokasi \\
\hline Wisata Pantai & Pantai Kartini & Di desa Bulu Kecamatan Jepara Kabupaten Jepara. \\
& Pantai Bandengan & Di desa Bandengan kecamatan Jepara Kabupaten Jepara. \\
& Pantai Blebak & Di desa Sekuro Kecamatan Mlonggo Kabupaten Jepara. \\
& Pantai Teluk Awur & Di desa teluk awur, Kecamatan Tahunan Kabupaten \\
& Jepara. \\
& Pantai Empu Rancak & Desa Karanggondang Kecamatan Mlonggo Kabupaten
\end{tabular}




\begin{tabular}{|c|c|c|}
\hline & Pantai Pailus & $\begin{array}{l}\text { Terletak di desa Karanggondang Kecamatan Mlonggo } \\
\text { Kabupaten Jepara. }\end{array}$ \\
\hline & Pantai Bringin & Di desa bumiharjo Kecamatan Keling Kabupaten Jepara. \\
\hline & Pantai Ombak Mati & Di desa bondo Kecamatan Bangsri Kabupaten Jepara. \\
\hline & Pantai Pungkruk & $\begin{array}{lll}\text { Dideda Mororejo Kecamatan Mlonggo Kabupaten } \\
\text { Jepara. }\end{array}$ \\
\hline \multirow[t]{4}{*}{ Wisata Alam } & $\begin{array}{l}\text { Air Terjun Songgo } \\
\text { Langit }\end{array}$ & $\begin{array}{l}\text { Di dukuh ngelencer desa bucu Kecamatan Kembang } \\
\text { Kabupaten Jepara. }\end{array}$ \\
\hline & Goa Tritip & $\begin{array}{l}\text { Terletak di ujungwatu Kecamatan donorojo Kabupaten } \\
\text { Jepara. }\end{array}$ \\
\hline & Goa Manik Pecatu & $\begin{array}{l}\text { Berada di desa sumanding, Kecamatan Kembang } \\
\text { Kabupaten Jepara. }\end{array}$ \\
\hline & Telaga Sejuta akar & Di desa plajan Kecamatan pakis aji Kabupaten Jepara. \\
\hline
\end{tabular}

Sumber: Dinas Pariwisata dan Kebudayaan Kabupaten Jepara, (2018)

Tabel 3

Daftar Objek Wisata Buatan di Kabupaten Jepara

\begin{tabular}{|c|c|c|c|}
\hline Kategori & $\begin{array}{c}\text { Nama Objek } \\
\text { Wisata }\end{array}$ & Lokasi & Keterangan \\
\hline Wisata & Kura-kura & Terletak ditempat & objek wisata ini memberikan sensasi \\
\hline \multirow[t]{4}{*}{ Buatan } & Ocean Park & $\begin{array}{l}\text { Pantai Kartini Di } \\
\text { desa Bulu Kecamatan } \\
\text { Jepara Kabupaten } \\
\text { Jepara. }\end{array}$ & $\begin{array}{l}\text { unik yang di mana membuat bangunan } \\
\text { berbentuk kura-kura dan didalamnya } \\
\text { terdapat aquarium yang di isi berbagai } \\
\text { jenis ikan yang menarik. }\end{array}$ \\
\hline & WB. Tiara Park & $\begin{array}{l}\text { Di JL.kenari di desa } \\
\text { purwogondo } \\
\text { Kecamatan } \\
\text { Kalinyamatan } \\
\text { Kabupaten Jepara. }\end{array}$ & $\begin{array}{l}\text { Objek wisata ini berupa waterboom yang } \\
\text { dimana tempatnya cukup luas. Tempat } \\
\text { objek wisata ini tidak hanya kolam air } \\
\text { saja tetapi juga ada 3D theater yang } \\
\text { dimana bisa menarik wisatawan. }\end{array}$ \\
\hline & $\begin{array}{l}\text { Jepara Ourland } \\
\text { Park }\end{array}$ & $\begin{array}{l}\text { Pantai Mororejo di } \\
\text { desa bandengan } \\
\text { Kecamatan Mlonggo } \\
\text { Kabupaten Jepara. }\end{array}$ & $\begin{array}{l}\text { Objek wisata ini yang berupa } \\
\text { waterboom terbesar dan terlengkap di } \\
\text { Jawa Tengah yang baru diresmikan } 2016 \\
\text { kemarin. Mengusung tema Eropa dan } \\
\text { Timur Tengah dan terletak dipinggir } \\
\text { pantai sehingga banyak menyediakan } \\
\text { wahana permainan di pinggir pantai } \\
\text { misalnya Banana boat, jetski dan banyak } \\
\text { lainnya. }\end{array}$ \\
\hline & $\begin{array}{l}\text { Gong } \\
\text { Perdamaian }\end{array}$ & $\begin{array}{l}\text { Di desa Plajan } \\
\text { Kecamatan Pakis Aji } \\
\text { Kabupaten Jepara. }\end{array}$ & $\begin{array}{l}\text { Objek wisata ini berupa Gong yang } \\
\text { cukup besar dan tidak hanya satu gong } \\
\text { saja melainkan ada } 3 \text { gong. Gong yang }\end{array}$ \\
\hline
\end{tabular}




$\begin{array}{ll}\text { Wisata Industri } & \text { Terletak didesa } \\ \text { Mulyoharjo } & \begin{array}{l}\text { Mulyoharjo } \\ \text { Kecamatan Jepara } \\ \text { Kabupaten Jepara. }\end{array} \\ & \text { Berada didesa tempur } \\ \text { Desa Wisata } & \text { kecamatan Keling } \\ \text { Tempur } & \text { kabupaten Jepara. }\end{array}$

Desa Petekeyan Berada didesa petekeyan Kecamatan tahunan Kabupaten jepara.

Desa Troso

Berada di desa troso pertama adalah gong Nusantara yang artinya perdaiaman bagi setiap pemeluk agama yang ada di Indonesia. Yang kedua gong perdamaian dunia, ditengah gong terdapat bentuk bola dunia dan sisisisnya terdapat gambar bendera diseluruh dunia. Gong ketiga adalah gong perdamian Asia-Afrika yang di gongnya terdapat bendara negara yang ikut konferensi Asia - Afrika.

wisata ini menyajikan berbagai bentuk kerajinan seni ukir Jepara sebagai ciri khas serta bisa menjadi oleh-oleh khas Jepara.

Wisata ini berkaitan dengan keindangan alam karena desa ini berada di tengahtengah bukit kecil yang masuk pada pegunungan muria. Tidak hanya keindahan alam saja yang terdapat di desa ini, melainkan juga terdapat reruntuhan candi yaitu candi bubrah dan candi angin. Selain itu juga wisatawan bisa berkeliling di kebun kopi yang berada di desa tempur ini.

Wisata ini memperlihatkan bagaimana proses pembuatan seni ukir khas Jepara. di tempat ini juga wisatan bisa belajar bagaimana membuat seni ukir khas jepara. selain bisa belajar, wisatawan juga bisa berbelanja furnitur ataupun pernak pernik hasil ukir warga desa petekeyan. Kecamtan Pecangaan kabupaten Jepara.
Wisata ini memperlihatkan bahwa jepara punya kain khas tenun asli jepara. jika wisatawan ingin melihat pembuatan ataupun ingin membeli kain tenun khas jepara bisa mampir ke tempat ini.

Sumber: Dinas Pariwisata dan Kebudayaan Kabupaten Jepara, (2018)

Mengingat ada banyaknya objek wisata di Kabupaten Jepara tidak memungkinkan Pemerintah daerah sendiri yang mengurusnya, perlu peran masyarakat untuk meningkatkan dan mengembangkan objek wista di Kabupaten Jepara. Agar Pemerintah daerah bisa memantau dan mengetahui maka objek wisata yang ada di Kabupaten Jepara harus Terdaftar di Pemerintah Daerah Kabupaten Jepara. Hal ini di atur Dalam Pasal 35 ayat (1) Peraturan Daerah No. 9 Tahun 2016 Tentang Penyelenggaraan Usaha Pariwisata yang berbunyi:'Untuk menyelenggarakan usaha 
Pariwisata sebagai mana Pasal 7, pengusaha wajib memiliki tanda daftar usaha pariwisata dari Bupati”.

Dengan adanya ketentuan Pasal ini, bukan berarti untuk membuka usaha pariwisata harus punya izin daftar. Dalam Peraturan Daerah No. 9 Tahun 2016 Tentang Penyelenggaraan Usaha Pariwisata juga terdapat Pasal yang di bebaskan dari pendaftaran usaha pariwisata yaitu untuk usaha pariwisata yang masih mikro atau kecil yang terdapat pada Pasal 35 ayat (3) yang berbunyi:"pengusaha perseorangan yang tergolong usaha mikro atau kecil sesuai dengan ketentuan Peraturan perundangundangan dibebaskan dari keharusan untuk melakukan pendaftaran usaha pariwisata". Itu sebabnya masih ada beberapa objek wisata yang ada di Kabupaten Jepara yang tidak terdaftar di Dinas Pariwisata dan Kebudayaan Kabupaten Jepara.

Pemerintah Daerah harus memmberikan dukungan regulasi sektor yang yang kuat di bidang pariwisata. Hal ini sesuai dengan amanat Pasal 79 ayat (3) Peraturan Daerah No.9 Tahun 2016 Tentang Penyelenggaraan Usaha Pariwisata. Yang berbunyi: "Pemerintah Daerah memberikan peluang dukungan dan fasilitas bagi usaha mikro dan kecil dibidang usaha pariwisata". Tetapi pada kenyataannya masih ada beberapa objek wisata yang tidak mendapatkan fasiltas seperti toilet umum, tempat sampah ataupun tempat penginapan bagi wisatawan dari Pemerintah daerah. Hal ini sangat di sanyangkan karena hal ini yang menyebabkan sulitnya berkembangan objek wisata tersebut dan juga roda perekonomian masyarakat sulit berkembang juga.

Berdasarkan Pasal 7 Peraturan Daerah No. 9 Tahun 2016 Tentang PenyelenggaraanUsaha Pariwisata yang berisi bidang usaha pariwisata meliputi: daya tarik wisata, kawasan pariwisata, jasa transportasi, jasa perjalanan wisata, jasa makanan dan minuman, penyediaan akomodasi, penyelenggaraan kegiatan hiburan dan rekreasi, penyelenggaraan pertemuan, perjalanan insentif, konferensi, dan pameran. Tidak akan bisa berjalan dengan baik tanpa ada fasilitas jalan yang baik, seperti akses jalan menuju objek wisata. hal ini, disebabkan masih banyaknya akses jalan menuju objek wisata yang kurang baik bahkan ada beberapa objek wisata yang tidak bisa di lalui oleh kendaraan.

Untuk saat ini Pemerintah Daerah Kabupaten Jepara lebih memfokuskan pada pengembangan objek wisata unggulan semata misalnya Pulau Karimun Jawa, Pantai Kartini, Pantai Tirta Samudra, Kura-Kura Ocean Park, dan Jepara Ocean Park. Dalam hal ini, butuh payung hukum berupa Perda yang bersifat "Lex Specilasi" untuk pengembangan infrastruktur pariwiasata yang masih minim tersebut. Jika ada payung hukum Perda yang jelas, maka ketersediaan dana alokas APBD di dibidang pengembangan infrastruktur pariwisat yang lebih teranggarkan secara sistemik dan kontinyu. Kondisi saat ini masih menjukkan kondisi kerusakan jalan dan kapasitas infrastruktur yang masih terbatas. Padahal infrastruktur yang dibutuhkan mencakup 35 objek wisata yang sudah terdata secara resmi di Dinas Pariwisata dan Kebudayaan Kabupaten Jepara. Selain jalan akses utama, fasilitas penunjang seperti ketersediaan 
kamar mandi umum maupun penginapan atau home stay pagi wisatawan lokal dan mancanegar juga penting mendapat perhatian utama.

Pemerintah Kabupaten Jepara juga segera membuat Perda-Perda dan Peraruran Bupatui terkait inventarisasi sejumlah yang belum terdaftar. Hal ini penting agar rencana induk pengembangan sektor pariwisata mampu menjangkau semua potensi objek wisata yang ada di Jepara. Akses jalan dan infrastruktur penunjang di kawasan objek wisata yang belum terdaftar juga sangat terbatas. Tentu hal ini tidak sesuai dengan Peraturan yang berlaku di Kabupaten Jepara. Ketentuan hukum pada Pasal 63 ayat (1) huruf (g) dalam Peraturan Daerah No.9 Tahun 2016 Tentang Penyelenggaraan Usaha Pariwisata yang berbunyi menegaskan bahwea dalam Penyelenggaraan Kepariwisataan Pemerintah Kabupaten Jepara memfasilitasi pengembangan daya tarik wisata baru".

Kebijakan hukum Pemerintah Kabupaten Jepara yang telah dilakukan dan perlu ditingkatkan lebih baik lagi di biidang pengembangan potensi dan ojek wisata setidaknya mencakup :

1. Memberikan hak sepenuhnya pengelolaan kepada Masyarakat.

Pemerintah daerah Kabupaten Jepara memberikan hak sepenuhnya kepada masyarakat sekitar bukan tanpa alasan, mengingat ada banyaknya objek wisata yang ada di Kabupaten Jepara maka tidak memungkinkan jika Pemerintah daerah mengelola sendiri semua objek wisata. Walaupun ada beberapa objek wisata yang dikelola oleh Pemerintah daerah Kabupaten Jepara sendiri misalnya objek wisata yang sudah menjadi andalan Kabupaten Jepara. Pemerintah daerah Kabupaten Jepara juga harus turut serta memperkaut regualsi hukum (Perda, Peraturan Dinas terkati, Peraturan Bupat) terkait dukungan infrastruktyur dan fasilitasa, sarana-prasaaran objek wisata yang di kelola oleh masyarakat, sesuai dengan amanat Pasal 79 ayat (3) Peraturan Daerah No. 9 Tahun 2016 Tentang Penyelenggaraan Usaha Pariwisata. Ketentuan Perda ini menegaskan Pemerintah Daerah memberikan peluang dukungan dan fasilitasi bagi usaha mikro dan kecil dibidang usaha pariwisata". Perlu diketahui, sebelum adanya Peraturan Daerah No. 9 Tahun 216 Tentang Penyelenggaraan Usaha Pariwisata, masyarakat sudah mengelola sendiri objek wisata yang ada di sekitar masyarakat itu sendiri.

Peraturan Daerah No. 9 Tahun 2016 Tentang Penyelenggaraan Usaha Pariwisata itu ada, bukan Pemerintah daerah Kabupaten Jepara mengambil alih pengelolaannya akan tetapi untuk memperkembangkan objek wisata yang sebelumnya sudah di kelola masyarakat sekitar agar lebih berkembang lagi sehingga bisa mengangkat perekonomian masyarakat sekitar. Peraturan Daerah No. 9 Tahun 2016 Tentang Penyelenggaraan Usaha Pariwisata dibuat agar pariwisata yang ada di Kabupaten Jepara bisa berjalan dengan baik dan bisa lebih berkembang lagi sehingga bisa dikenal di seluruh bangsa Indoneisa.

Pemerintah daerah Kabupaten Jepara wajib melakukan pengawasan terhadap penyelenggaraan Usaha Pariwisata di Kabupaten Jepara sesuai dengan Pasal 76 ayat (1) Peraturan Daerah No. 9 Tahun 2016 Tentang Penyelenggaraan Usaha Pariwisata yang 
berbunyi:"Bupati berwenang melakukan pengawasan terhadap penyelenggaraan usaha pariwisata yang ada di daerah". Dalam hal ini bupati tidak melakukan pengawasan langsung ataupun terjun langsung mengawasi melainkan menyerahkan kepada Dinas Pariwisata dan juga di bantu oleh tim pengawas penyelenggaraan usaha pariwisata sesuai dengan Pasal 76 ayat (3) Peraturan Daerah kabupaten Jepara No. 9 Tahun 2016 tentang Penyelenggaraan Usaha Pariwisata yang berbunyi:'Dalam melakukan pengawasan terhadap penyelenggaraan usaha pariwisata sebagaimana dimaksud pada ayat (2), Kepala Dinas dibantu oleh tim pengawasan Penyelenggaraan Usaha Kepariwisataan yang dibentuk dengan Keputusan Bupati”.

Dalam hal ini, untuk mengembangkan suatu objek wisata diperlukan penanganan yang serius dan mengerti kondisi lokasi objek wisata maupun sekitar objek wisata dan masyarakatlah yang lebih tepat mengurusnya karena masyarakat sekitar lebih mengerti kondisi objek wisata dan konsidi lingkungan sekitar objek wisata.

2. Kebijakan Pemerintah daerah membuat desa unggulan atau desa wisata.

Pemerintah daerah Kabupaten Jepara sedang konsentrasi mengembangkan desa unggulan atau desa wisata di Kabupaten Jepara. di samping menarik wisatawan, juga bisa menambah objek wisata yang ada di Kabupaten Jeparasehingga meningkatkan perekonomian Masyarakat Jepara sendiri. Sesuai dengan Peraturan Daerah No.9 Tahun 2016 Tentang Penyelenggaraan Usaha Pariwisata di Kabupaten Jepara pada Pasal 74 ayat (3) yang berbunyi: "Ketentuan lebih lanjut mengenai peran serta masyarakat sebagaimana pada ayat (1) diatur dengan Peraturan Bupati”. Sehingga inilah yang menjadi landasan Keputusan Bupati Jepara Nomor 55/179 Tahun 2018 Tentang Penetapan Lokasi Desa Unggulan Kabupaten Jepara di buat.Tujuan utama dibuat desa wisata ataupun desa unggulan adalah untuk meningkatkan perekonomian masyarakat agar lebih berkembang dan bisa menambah objek wisata lokal agar lebih menarik wisatawan asing maupun lokal.

\section{Kebijakan Pemerintah dalam Retribusi}

Pada Undang-Undang No.28 Tahun 2009 Tentang Pajak Daerah dan Retribusi Daerah Pada Pasal 156 ayat (1) yang berbunyi:'Retribusi ditetapkan dengan peraturan Daerah". Inilah yang menjadi landasan kenapa Pemerintah Daerah Kabupaten Jepara membuat Peraturan Daerah No. 6 Tahun 2016 Tentang Perubahan Atas Peraturan Daerah Kabupaten Jepara No. 26 Tahun 2010 Tentang Retribusi Tempat Rekreasi. Pada Pasal 16 ayat (1) dalam Peraturan Daerah No. 6 Tahun 2016 Tentang Perubahan Atas Peraturan Daerah Kabupaten Jepara No. 26 Tahun 2010 Tentang Retribusi rekreasi berbunyi:"Bupati dapat memberikan pengurangan, keringanan, dan pembebasan retribusi”. Dalam Pasal 16 ini, Pemerintah Daerah tidak menyama ratakan retribusi objek wisata dan juga tidak semua objek wisata ada biaya retribusinya. Hanya sedikit objek wisata yang dikenakan biaya retribusi yang ada di Kabupaten Jepara yaitu objek wisata yang dikelola sendiri oleh Pemerintah daerah. 
Pada Pasal 9 dalam Peraturan Daerah No. 6 Tahun 2016 Tentang Perubahan Atas Peraturan Daerah Kabupaten Jepara No. 26 Tahun 2010 Tentang Retribusi rekreasi berbunyi: "Struktur dan besarnya yarif retribusi daerah ditetapkan sebagaiman tercantum dalam lampiran yang merupakan bagian tidak terpisahkan dari peraturan daerah ini".Jadi dalam Peraturan tersebut besar tarif dan objek mana saja yang di kenakan tarif retribusi sudah di atur dalam Peraturan Daerah No. 6 Tahun 2016 Tentang Perubahan Atas Peraturan Daerah Kabupaten Jepara No. 26 Tahun 2010 Tentang Retribusi rekreasi. Objek wisata yang di kenakan tarif retribusi meliputi:
a. Pantai Kartini
b. Pantai Tirta Samudra
c. Benteng Portugis
d. Pulau Panjang
e. Museum Kartini
f. Kura-Kura Ocean Park
g. Wisatawan Nusantara Karimunjawa
h. Wahana Permainan anak
i. Kolam renang / Waterboom

Sehingga selain objek wisata di atas berarti tidak dikenakan tarif Retribusi. Mengingat perkembangan setiap objek wisata yang ada di Kabupaten Jepara berbedabeda dan juga banyaknya objek wisata di Kabupaten Jepara, sehingga perlu adanya Peraturan khusus tentang retribusi rekreasi. Sekarang ada Kebijakan baru dari Pemerintah daerah Kabupaten Jepara yang dimana programnya menggratiskan tiket masuk ke objek wisata yang ada di Kabupaten Jepara di hari biasa tetapi di hari libur masih di kenakan tarif masuk ke objek wisata di Kabupaten Jepara. Hal ini dilakukan agar para wisatawan lebih tertarik mengunjungi objek wisata yang ada di Kabupaten Jepara.

\section{Menyediakan Kantor TIC Jepara (Tourism Information Center)}

TIC Jepara memberikan semua informasi mengenai semua objek wisata, Penginapan ataupun Hotel maupun menyediakan paket liburan di objek wisata di Kabupaten Jepara serta menyediakan pemandu wisata bagi para wisatawan lokal maupun mancanegara. TIC Jepara memiliki web di internet yang bisa di akses oleh semua orang selama memiliki jaringan internet yang alamat situs webnya tic.Jepara.go.id. bagi wisatawan lokal maupun mancanegara yang ingin tau tentang semua pariwisata yang ada di Kabupaten Jepara bisa ke kantor TIC yang berada di tengah pusat Kota Jepara secala langsung maupun bisa lewat akses situs webnya.

Banyak yang tidak mengetahui bahwa Kabupaten Jepara punya kain Tenun khas Jepara yang harus tetap dilestarikan dan dijaga. Berkat Pemerintah daerah Kabupaten 
Jepara banyak wisatawan mancanegara maupun wisatawan lokal yang tahu sehingga banyak wisatawan yang membeli sebagian oleh-oleh dari Kota Jepara. Dalam menentukan keberhasilan atau tidaknya kebijakan Pemerintah daerah Kabupaten Jepara tidak menggunakan kepuasan pengunjung sebagai salah satu indikator. Banyaknya pengunjung yang datang belum mencukupi untuk menyatakan kebijakan Pemerintah daerah iu berhasil atau pun tidak. Kepuasan pengunjung yang telah melakukan kunjungan dan menerima pelayanan serta menggunakan fasilitas yang ada dapat menjadi koreksi bagi Pemerintah daerah Kabupaten Jepara mengingat pengunjung wisatawan sebagai penunjang pengembangan-pengembangan objek wisata yang ada di Kabupaten Jepara.

Pemerintah daerah Kabupaten Jepara sudah mengalokasikan dana ke setiap objek wisata yang ada di Kabupaten Jepara, akan tetapi Pemerintah daerah Kabupaten Jepara memberikan dana lebih ke objek wisata yang sudah berkembang untuk mengembangkan lagi objek wisata yang ada di Kabupaten Jepara. Sehingga terjadi perbedaan pengembangan yang sangat jauh antara objek wisata yang sudah berkembang dengan objek wisata yang belum berkembang.Untuk menuju objek wisata yang ada di Jepara, harus menggunakan kendaraan pribadi tidak bisa menggunakan kendaraan umum. Walaupun di Kabupaten Jepara ada alat transportasi umum, namun hanya melintasi jalanan utama yang ada di Kabupaten Jepara.Tingginya wisatawan yang berkunjung ke Jepara yang sangat banyak pada musim liburan yang terkadang kurangnya pemandu wisata.

Terkadang banyaknya wisatawan asing yang tidak bisa menggunakan bahasa Indonesia sehingga membutuhkan pemandu wisata, karena kebanyakan orang lokal Kota Jepara yang tidak bisa menggunakan bahasa asing. Sekarang sudah banyak wisatan asing yang pergi mengunjungi objek wisata yang ada di karimunjawa yang dimana pada musim-musim liburan sangat banyak wisatawan asing yang datag ke Kota Jepara untuk berkunjung ke Pulau Karimunjawa. Hampir semua objek wisata yang ada di Jepara menyatu dengan perkampungan penduduk, sehingga lahan objek wisata menjadi terbatas misalkan tempat parkir yang sempit karena kurangnya lahan sehingga sulit untuk diperluas area parkir pengunjung. Tanpa adanya lahan yang memadai akan sangat sulit mengembangkan objek wisata yang ada di Kabupaten Jepara.Tidak semua objek wisata yang ada di Kabupaten Jepara di sediakan toilet umum, tempat sampah maupun penginapan seperti villa maupun hotel beserta juga warung makan di tempat lokasi objek wisata. Hal ini sangat sulit untu menarik wisatawan lokal maupun asing karena fasilitas penunjang sangat berpengaruh dalam pariwisataan tanpa adanya fasilitas yang memadai objek wisata tersebut tidak akan bisa berkembang. Terkadang sebagus apapun objek wisatanya tetapi tidak di dukung fasilitas yang memadai misal toilet umum, warung makan serta tempat penginapan bagi wisatawan akan sangat sulit untuk berkembang. Karena fasilitas di objek wisata secara tidak langsung membuat wisatawan tertarik untuk mengunjunginya. 


\section{Simpulan}

Penguatan payung hukum di bidang pengelolaan objek pariwisat di Kabupaten Jepara dalam pengembangan objek pariwisata di Kabupaten Jepara telah dilakukan sesuai dengan Peraturan Daerah No. 9 Tahun 2016 Tentang Penyelenggaraan Usaha Pariwisata, serta Peraturan Daerah No.6 Tahun 2016 Tentang Perubahan Atas Peraturan Daerah Kabupaten Jepara No.26 Tahun 2010 Tentang Retribusi Tempat Rekreasi. Akan tetapi belum semua objek wisata di Kabupaten Jepara mempunyai payung hukum yang kuat. Hal ini disebabkan karena penguatan payung hukum masih terfokus pada objek wisata yang sudah terdata secara resmi padahal masih banyak potensi objek pariwisata yang perlu segera mendapat perhatian khususnya penguatan regulasi pengelolaan dan pemanfaatannya secara legal dan berbasis partisipatif masyarakat. Pemda Jepara perlu membuat evaluasi secara menyeluruh terkati produk legislasi daerah khususnya dibidang pariwisata guna memastikan kebutuhan payunbg hukum di bidang pariwisata daerah. Selain itu, perlu ditingkatkan, program pemberdayaan objek pariwisata berbasisi masyarakarat yang harus diatur dalam Perda-Perda atau regulasi sektoral terkait. Hal ini penting agar tidak terjadi praktek pungutan liar dan menambah nilai ekonomis bagi daerah dani masyarakat pada umumnya.

\section{Daftar Pustaka}

\section{Jurnal}

Deddy Prasetya Maha Rani. (2014). "Pengembangan Potensi Pariwisata Kabupaten Sumenep, Madura, Jawa Timur”. Jurnal Politik Muda. Vol. 3 No. 3.

Nofia Farida. (2013). “Objek Wisata Pantai Tirto Samudra Berpotensi Meningkatkan Kehidupan Sosial Ekonomi Masyarakat”. Jurnal Ilmiah Pendidikan Geografi. Vol. 1 No. 1.

Asep Yudha Wirajaya. (2016). "Pengembangan Pariwisata Budaya di Daerah Jepara”. Jurnal Etnografi. Vol. 16 No. 1.

\section{Skripsi}

Arifah. (2012). "Pengembangan Pantai Tirto Samudro bandengan". Skripsi. Tidak diterbitkan. Fakultas Teknik Universitas Diponegoro Semarang.

\section{Regulasi}

Undang-Undang Republik Indonesia Nomor 10 Tahun 2009 Tentang Pariwisata.

Undang-Undang Republik Indonesia Nomor 23 Tahun 2014 Tentang Pemerintah Dearah.

Undang-Undang Republik Indonesia Nomor 9 Tahun 2015 Perubahan kedua Atas Undang-Undang Republik Indonesia Nomor 23 Tahun 2014 Tentang Pemerintah Daerah. 
Peraturan Daerah Kabupaten Jepara Nomor 9 Tahun 2016 Tentang Penyelenggaraan Usaha Pariwisata.

Peraturan Daerah Kabupaten Jepara Nomor 6 Tahun 2016 Tentang Perubahan atas Peraturan Daerah Kabupaten Jepara Nomor 26 Tahun 2010 TentangRetribusi Tempat Rekreasi. 